\title{
Pengembangan Model Pembelajaran Kooperatif Tipe Cooperatif Integrated Reading and Composition (CIRC) untuk Meningkatkan Hasil Belajar Siswa SMA NW Suralaga Lombok Timur
}

\begin{abstract}
Abstrak
Penelitian ini bertujuan untuk menghasilkan bahan ajar buku model pembelajaran kooperatif tipe cooperative integrated reading and composition (CIRC) dalam meningkatkan hasil belajar siswa kelas X SMA NW Suralaga. Penelitian ini merupakan penelitian pengembanngan dengan lima prosedur penelitian yaitu, pendahuluan, pengembangan produk awal, uji produk awal, uji produk akhir, dan produk akhir. Berdasarkan hasil penelitian didapatkan bahwa terdapat perbedaan hasil belajar setelah menggunakan bahan ajar model pembelajaran kooperatif kelas $\mathrm{X}$ (sepuluh) yang dikembangkan dengan teknik CIRC. Hal ini berarti bahwa hasil belajar sebelum dan sesudah menggunakan bahan ajar tidak sama. Jadi dapat dikatakan terdapat perbedaan yang cukup signifikan antara hasil belajar siswa sebelum dan sesudah menggunakan paket pembelajaran. Dilihat dari respon guru memiliki nilai persentase rata-rata $94,2 \%$, respon siswa memiliki nilai persentase rata-rata 93,2\%, dan hasil belajar siswa dengan menggunakan paket bahan ajar model pembelajaran kooperatif ini memperoleh nilai rata-rata $84,1 \%$ sehingga dapat dikatakan efektif digunakan dalam proses pembelajaran di SMA NW Suralaga Kabupaten Lombok Timur.
\end{abstract}

Kata Kunci: Pembelajaran Kooperatif, Tipe CIRC, Hasil Belajar

\begin{abstract}
This study aims to produce teaching materials for cooperative learning model books of cooperative integrated reading and composition (CIRC) types in improving the learning outcomes of class X students at SMA NW Suralaga. This research is a development research with five research procedures, namely, introduction, initial product development, initial product test, final product test, and final product. Based on the results of the study, it was found that there were differences in learning outcomes after using teaching materials for class X (ten) cooperative learning models developed with the CIRC technique. This means that the learning outcomes before and after using teaching materials are not the same. So it can be said that there is a significant difference between student learning outcomes before and after using the learning package. Judging from the teacher's response has an average percentage value of $94.2 \%$, student responses have an average percentage value of $93.2 \%$, and student learning outcomes using the teaching material package of this cooperative learning learning model get an average value of 84.1 $\%$ so that it can be said to be effectively used in the learning process at SMA NW Suralaga, East Lombok Regency.
\end{abstract}

Keywords: Cooperative Learning, Type of CIRC, Student Learning Outcomes 


\section{Pendahuluan}

Pelaksanaan pendidikan di sekolah, guru memiliki peran penting untuk memaksimalkan fungsi pendidikan tersebut. Dimulai dari penguasaan materi ajar, kemampuan memanajemen kelas, memberikan motivasi dan penguatan kepada peserta didik, serta kemampuan mengadakan variasi strategi atau model pembelajaran adalah potensi yang harus dimiliki seorang guru. Penggunaan model pembelajaran yang bervariasi ditujukan untuk meningkatkan efektivitas belajar siswa dalam memahami setiap ilmu yang disampaikan oleh guru sehingga tujuan pembelajaran dapat terwujud selaras dengan hasil belajar siswa yang semakin baik. Namun pada kenyataannya sampai saat ini model pembelajaran yang paling dominan digunakan oleh guru adalah model pembelajaran konvensional terutama ceramah. Setiap pembelajaran disampaikan secara monoton hanya dengan ceramah saja tanpa mengadakan variasi sebagai bentuk inovasi guna meningkatkan minat siswa dalam belajar.

Model pembelajaran pada dasarnya merupakan bentuk pembelajaran yang tergambar dari awal sampai akhir yang disajikan secara khas oleh guru (Komalasari, 2011: 57). Model pembelajaran merupakan bingkai dari penerapan suatu pendekatan, metode, dan teknik pembelajaran. Model pembelajaran kooperatif merupakan pembelajaran yang memberikan kesempatan kepada siswa untuk bekerja sama dengan sesama siswa dalam tugas yang terstruktur (Lie, 2002: 12).

Tujuan penting lain dari pembelajaran kooperatif adalah untuk mengajarkan kepada siswa keterampilan kerjasama dan kolaborasi. Keterampilan ini amat penting untuk dimiliki dalam masyarakat dimana sebagian besar dilakukan dalam organisasi yang saling bergantungan satu sama lain dan dimana masyarakat secara budaya semakin beragam (Ibrahim, dkk., 2000: 9). Tujuannya agar hasil belajar siswa semakin baik dimana hasil belajar memuat kemampuan yang dimiliki siswa setelah ia menerima pengalaman belajar (Sudjana, 2009: 22). Hasil belajar adalah kemampuan-kemampuan yang dimiliki siswa setelah ia menerima pengalaman belajarnya dimana terjadi perubahan tingkah laku pada diri siswa, yang dapat diamati dalam bentuk perubahan pengetahuan, sikap, dan keterampilan (Hamalik, 2013: 90).

Berdasarkan observasidi SMA NW Suralaga bahwa dalam proses pembelajaran guru menyampaikan materi pembelajaran, dan sesekali diberi tugas rumah. Kondisi pembelajaran seperti ini belum sepenuhnya dapat memfasilitasi belajar siswa, dengan 
demikian hasil belajar siswa cenderung rendah. Akibatnya bagi siswa yang mempunyai latar belakang kemampuan yang lebih dari teman-temannya mereka akan semakin berkembang, sedangkan siswa yang memiliki kemampuan yang kurang maka mereka akan semakin tertinggal oleh teman-temannya yang lain. Permasalahannya masih terfokus pada metode yang digunakan oleh guru lebih dominan menggunakan metode ceramah sehingga menyebabkan kompetensi yang diharapkan dalam pembelajaran tidak dapat tercapai secara optimal, hal ini dapat dilihat dengan rendahnya hasil belajar siswa. Oleh karena itu peneliti mengajukan model pembelajaran tipe cooperative integrated reading and composition (CIRC) dalam pelaksanaan pembelajaran ekonomi. Model pembelajaran tipe CIRC adalah model pembelajaran yang menggunakan tim-tim kooperatif untuk membantu para siswa mempelajari kemampuan memahami bacaan yang dapat diaplikasikan secara luas (Slavin, 2008: 203). Model pembelajaran kooperatif tipe CIRC digunakan dalam kegiatan pembelajaran untuk meningkatkan hasil belajar siswa sangat dibutuhkan oleh peserta didik kelas X SMA NW Suralaga pada mata pelajaran ekonomi.

Penelitian ini didukung oleh penelitian-penelitian terdahulu yang berhubungan dengan fokus kajian dan analisis penulis. Penelitian yang dilakukan oleh Wilis Indah Purnamasari (2016) yang menunjukan bahwa uji hipotesis tentang pengaruh model pembelajaran cooperative integrated reading and composition (CIRC) telah membuktikan bahwa penggunaan model CIRC memberikan pengaruh yang signifikan terhadap kemampuan menemukan kalimat utama dalam paragraf kelas IV SDN Blimbing dengan nilai rata-rata 81,46. Penelitian Ipuh (2015) menunjukkan bahwa CIRC pembelajaran kooperatif terpadu membaca dan komposisi (CIRC) dapat secara efektif meningkatkan keterampilan membaca dan menulis siswa dalam bahasa Inggris. Ada penelitian Parinu, Darmawiguna, \& Wahyuni (2013) tentang pengaruh model pembelajaran cooperative integrated reading and composition (CIRC) terhadap hasil belajar TIK siswa kelas VII (Studi Kasus: SMP Negeri 4 Singaraja) tahun ajaran 2012/2013. Penelitian ini menunjukkan keberhasil model pembelajaran kooperatif tipe CIRC. Kemudian ada penelitian Ariyandika, Rohana, dan Jayanti (2017) yang meneliti tentang. pengaruh model pembelajaran kooperatif tipe CIRC terhadap kemampuan pemecahan masalah matematis siswa di SMP Negeri 22 Palembang dan penelitian Gustariani (2017) tentang penerapan model pembelajaran kooperatif tipe CIRC untuk 
meningkatkan hasil belajar Fisika pada pokok bahasan gejala dan ciri ciri gelombang siswa kelas XII SMAN 9 Pekanbaru. Kedua penelitian ini menunjukkan bahwa model pembelajaran tipe CIRC signifikan dalam pembelajaran di kedua sekolah tempat diterapkan.

Penelitian-penelitian terdahulu peneliti jadikan sebagai acuan dalam melaksanakan penelitian ini. Keberbedaan dengan penelitian ini pada pengembangan model pembelajaran yang dilakukan. Oleh karena itu urgensi penelitian ini terletak pada pengembangan model pembelajaran yang digunakan dalam pelaksanaan pembelajaran. Adapun tujuan penelitian ini adalah untuk mengetahui kelayakan pengembangan model pembelajaran kooperatif dengan tipe CIRC dalam meningkatkan hasil belajar siswa kelas X SMA NW Suralaga, dan mengetahui pengembangan model pembelajaran kooperatif dengan teknik CIRC dalam meningkatkan hasil belajar siswa kelas X SMA NW Suralaga.

\section{Metode Penelitian}

Jenis penelitian dalam penelitian ini adalah penelitian pengembangan yang menggunakan model pengembangan Borg \& Gall (Borg \& Gall, 2003). Dalam pengembangan bahan ajar ini, prosedur pengembangan dilakukan melaui lima prosedur penelitian. Produk akhir merupakan tahapan bahwa produk model pembelajaran kooperatif tipe CIRC untuk kelas X yang telah diuji cobakan dan telah divalidasi oleh ahli bahasa dan ahli materi, dan dinilai oleh peserta didik dan guru ekonomi. Model pembelajaran kooperatif tipe CIRC tersebut kemudian direvisi dan kemudian dicek lagi sehingga buku model pembelajaran kooperatif tipe CIRC dirasa sudah layak untuk digunakan. Wujud dari produk ini berupa Buku model pembelajaran kooperatif tipe CIRC dapat digunakan sebagai buku pembelajaran peserta didik kelas $\mathrm{X}$, khususnya peserta didik kelas X SMA NW Suralaga.

Instrumen pengumpulan data yang digunakan dalam penelitian ini adalah angket. Angket untuk mengumpulkan data kuantitatif dan kualitatif. Data ini digunakan untuk mengetahui bagaimana ketepatan rancangan produk sebagai buku pembelajaran dari ahli materi dan ahli bahasa, serta tanggapan peserta didik dan guru ekonomi di SMA NW Suralaga terhadap produk yang telah dikembangkan. Data hasil penelitian pengembangan ini adalah berupa tanggapan tim ahli terhadap kualitas produk yang dikembangkan dan respon siswa terhadap produk setelah digunakan dalam proses pembelajaran. Teknik 
analisis data untuk validasi ahli dengan cara menghitung skor yang diperoleh melalui angket dengan menggunakan skala likert. Sedangkan teknik analisis data untuk respon guru dan respon siswa dengan menggunakan angket.

\section{Pembahasan}

\section{Penelitian Pendahuluan}

Model pembelajaran yang dikembangkan dalam penelitian ini adalah model pembelajaran kooperatif tipe CIRC pada mata pelajaran ekonomi. Pengemangan model ini dilakukan dengan menggunakan model Borg and Gall. Mengacu pada metode dan prosedur penelitian. Pengembangan dalam penelitian ini hanya sampai pada tahap revisi produk. Penelitian pengembangan ini telah dilakukan dengan menghasilkan produk berupa buku model pembelajaran kooperatif tipe CIRC. Berikut akan di jelaskan tentang hasil yang didapatkan setelah malakukan pengembangan model pembelajaran. Penelitian pendahuluan yang dilakukan yakni survei lapangan. Survei lapangan dilakukan untuk mendapatkan data terkait dengan kebutuhan, ketersediaan kondisi kurikulum dan bahan ajar yang digunakan oleh siswa kelas X di Sekolah Mengeah Atas (SMA) NW Suralaga. Model pembelajaran ekonomi untuk SMA Kelas X IPS dikembangkan berdasarkan analisis kebutuhan yang disimpulkan yang diperoleh melalui berbagai informasi.

Survei lapangan tersebut dilakukan di SMA NW Suralaga. Berdasarkan kegiatan observasi, wawancara, dan angket ditemukan beberapa permasalahan yang ada dilapangan seperti; a) Tetode yang digunakan guru masih dominan, b) Tingkat keaktifan siswa masih kurang atau pasif c) Metode yang digunakan guru dalam pembelajaran belum bervariatif, d) Kurangnya motivasi siswa terhadap mata pelajaran ekonomi, e) Rendahnya hasil belajar siswa. Dari uraian permasalahan tersebut, maka dalam penelitian ini, peneliti mengembangkan model pembelajaran kooperatif CIRC dalam meningkatkan hasil belajar siswa kelas $\mathrm{X}$.

\section{Pengembangan Produk Awal}

Pengembangan model pembelajaran kooperatif tipe CIRC dikembangkan berdasarkan tahap analisis berbagai macam kebutuhan yang diperlukan, mulai dari analisis kebutuhan siswa. Pengembangan model pembelajaran kooperatif tipe CIRC ini merancangan output yaitu, model pembelajaran tipe CIRC, silabus dan RPP. Pada tahap 
pengembangan ini merupakan tahap awal dari kegiatan penelitian dan pengembangan. Peneliti merancang dan mengembangkan model pembelajaran sesuai dengan yang telah direncanakan. Produk yang dikembangkan adalah model pembelajaran kooperatif tipe CIRCyang digunakan oleh siswa dan guru. Bahan ajar tersebut diuji kevalidannya sebelum digunakan oleh siswa melalui berbagai tahapan yang sesuai dengan model penelitian dan pengembangan Borg and Gall. Selain mengembangkan bahan ajar, peneliti juga mengembangkan beberapa instrumen untuk mendukung pelaksanaan validasi dan uji coba bahan ajar. Adapun instrumen yang dimaksud antara lain: a) instrumen validasi bahan ajar oleh ahli; b) lembar respon guru dan lembar respon siswa.

\section{Uji Coba Produk Awal}

\section{Data Hasil Validasi Isi/Materi}

Validasi ahli Isi/Materi sangat diperlukan guna mengevaluasi isi/materi dalam buku model pembelajaran yang sudah di kembangkan sebelum dinyatakan layak untuk digunakan oleh guru. Ahli isi/materi atau validator yang dipilih dalam penelitian ini adalah Bapak Ihsan, M.Pd. validator diberikan I buku model pembelajaran beserta instrumen penilaian atau lembar validasi. Adapun data yang diperoleh adalah data kuantitatif berupa skor terhadap model pembelajaran dan data kualitatif berupa tanggapan, kritik, saran, dan perbaikan untuk model pembelajaran tersebut.

Adapun rincian hasil validasi materi terhadap model pembelajaran, sedangkan hasil validasi isi/materi, model pembelajaran pegangan guru dijabarkan pada tabel 1 .

\section{Tabel 1. Hasil Validasi Ahli Materi/Isi}

\begin{tabular}{|c|c|c|c|c|c|}
\hline \multirow[b]{2}{*}{ No } & \multirow[b]{2}{*}{ Butir Penilaian } & \multicolumn{4}{|c|}{ Tingkat Penskoran } \\
\hline & & 1 & 3 & 4 & 5 \\
\hline 1 & $\begin{array}{l}\text { Materi yang disajikan dalam model } \\
\text { pembelajaran yang di kembangkan memiliki } \\
\text { subtansi yang benar }\end{array}$ & & & & \\
\hline 2 & $\begin{array}{l}\text { Uraian yang dijabarkan dalam model } \\
\text { pembelajaran ini sesuai dengan kebutuhan } \\
\text { siswa dalam pembelajaran ekonomi }\end{array}$ & & & & \\
\hline 3 & $\begin{array}{l}\text { Model pembelajaran yang dikembangkan } \\
\text { memiliki manfaat untuk menambah wawasan } \\
\text { siswa }\end{array}$ & & & & $\checkmark$ \\
\hline 4 & $\begin{array}{l}\text { Gaya dan ketetapan bahasa yang disajikan } \\
\text { dalam model pembelajaran kooperatif tipe } \\
\text { CIRC mudah dipahami }\end{array}$ & & & & $\checkmark$ \\
\hline 5 & $\begin{array}{l}\text { Penggunaan bahasa dalam model pembelajaran } \\
\text { mudah dimengerti atau dipahami }\end{array}$ & & & & $\checkmark$ \\
\hline
\end{tabular}




\begin{tabular}{|c|c|c|c|}
\hline 6 & Kejelasan urutan pembelajaran & $\checkmark$ & \\
\hline 7 & Kemenarikan buku dari segi judul dan cover & $\checkmark$ & \\
\hline 8 & $\begin{array}{l}\text { Kejelasan } \\
\text { pembelajaran }\end{array}$ princian langkah-langkah & & $\checkmark$ \\
\hline 9 & $\begin{array}{l}\text { Huruf yang digunakan dalam buku model } \\
\text { pembelajaran tepat dan mudah untuk dibaca }\end{array}$ & & $\checkmark$ \\
\hline \multirow[t]{3}{*}{10} & $\begin{array}{l}\text { Daftar isi sudah runtut, jelas dan mudah } \\
\text { dipahami }\end{array}$ & & $\checkmark$ \\
\hline & Skor Total & 36 & \\
\hline & Persentase & $72 \%$ & \\
\hline
\end{tabular}

Hasil analisis data terhadap validasi isi/materi bahan ajar diperoleh nilai rata-rata sebesar $72 \%$ setelah dikonversi pada tabel tingkat kevalidan, materi dalam bahan ajar tersebut termasuk dalam katagori "cukup valid".

\section{Data Hasil Validasi Bahasa}

Validasi bahan ajar bertujuan untuk mengevaluasi aspek kesesuaian penggunaan bahasa dengan kaidah bahasa indonesia yang baik dan benar, konsistesi penggunaan istilah, lambang/simbol, serta keterbacaan dan kekomunikatifan bahan ajar.

Tabel 2. Hasil Validasi Ahli Bahasa

\begin{tabular}{|c|c|c|c|c|c|c|}
\hline \multirow{2}{*}{ No } & \multirow{2}{*}{ Butir Penilaian } & \multicolumn{5}{|c|}{ Tingkat Penskoran } \\
\hline & & 1 & 2 & 3 & 4 & 5 \\
\hline 1 & Sistematika penulisan & & & & $\checkmark$ & \\
\hline 2 & Kesesuaian dengan EYD & & & $\checkmark$ & & \\
\hline 3 & $\begin{array}{l}\text { Kalimat-kalimat yang digunakan dalam } \\
\text { bahan ajar jelas dan mudah dipahami }\end{array}$ & & & $\checkmark$ & & \\
\hline 4 & Kekomunikatifan bahasa & & & & $\checkmark$ & \\
\hline 5 & Keefektifan bahasa dalam panduan & & & & $\checkmark$ & \\
\hline 6 & Ketetapan penggunaan istilah & & & & $\checkmark$ & \\
\hline 7 & Ketetapan penyusunan struktur kalimat & & & & $\checkmark$ & \\
\hline 8 & $\begin{array}{l}\text { Kalimat-kalimat yang digunakan dalam } \\
\text { modul jelas dan mudah dipahami }\end{array}$ & & & & $\checkmark$ & \\
\hline 9 & Konsistensi tulisan yang digunakan & & & $\checkmark$ & & \\
\hline 10 & Sistematika penulisan & & & & & $\checkmark$ \\
\hline 11 & Penggunaan istilah simbol ikon. & & & & $\checkmark$ & \\
\hline 12 & $\begin{array}{l}\text { Keterkaitan antar kalimat, antar alinea, dan } \\
\text { antar bab }\end{array}$ & & & & $\checkmark$ & \\
\hline 13 & Keefektifan bahasa & & & $\checkmark$ & & \\
\hline 14 & Spasi baris yang digunakan dalam modul & & & & $\checkmark$ & \\
\hline 15 & $\begin{array}{l}\text { Bahasa yang digunakan mudah atau tidak } \\
\text { menimbulkan makna ganda (ambigu }\end{array}$ & & & & $\checkmark$ & \\
\hline & $\begin{array}{l}\text { Skor Total } \\
\text { Persentase }\end{array}$ & & & & & \\
\hline
\end{tabular}


Hasil analisis data terhadap validasi isi/materi bahan ajar diperoleh nilai rata-rata sebesar $76 \%$ setelah dikonversi pada tabel tingkat kevalidan, materi dalam bahan ajar tersebut termasuk dalam katagori "cukup valid".

\section{Revisi Uji Validasi}

Produk yang dikembangkan untuk divalidasi adalah model pembelajaran kooperatif tipe CIRC. Adapun komentar dan saran revisi oleh ahli materi bahwa bahwa produk yang berupa buku model sudah bisa digunakan di dalam penelitian. Akan tetapi ada bagian tertentu yang perlu diperbaiki: (1) cover perlu diubah sesuaikan dengan materi isi. Revisi oleh ahli bahasa diperoleh data berupa data kualitatif, saran dan juga komentar sebagai acuan untuk melakukan revisi terhadap produk yang dikembangkan. Akan tetapi ada bagian tertentu yang diperbaiki yakni, gunakan kalimat efektif, dan gunakan pedoman umum ejaan bahasa indonesia.

\section{Uji Coba produk}

\section{Data Hasil Uji Coba Kelompok Kecil}

Uji coba kelompok kecil bertujuan untuk mengetahui tingkat kevalidan bahan ajar yang telah divalidasi ahli sebelum digunakan oleh siswa kelas X. Uji coba kelompok kecil dilakukan pada hari Sabtu, 11 Agustus 2018 dengan cara memberikan angket kepada 7 orang siswa kelas X Sekolah Menengah Atas (SMA) NW Suralaga. Berikut disajikan data hasil uji coba kelompok kecil pada tabel 3 di bawah ini.

Tabel 3. Hasil Uji Coba Kelompok Kecil

\begin{tabular}{|c|c|c|c|c|c|c|c|c|}
\hline \multirow[b]{2}{*}{ No. } & \multirow{2}{*}{ Aspek yang Dinilai } & \multicolumn{7}{|c|}{ Skor Siswa ke- } \\
\hline & & 1 & 2 & 3 & 4 & 5 & 6 & 7 \\
\hline 1 & $\begin{array}{l}\text { Materi dalam perangkat lengkap dan mudah } \\
\text { untuk dipahami }\end{array}$ & 5 & 5 & 5 & 5 & 5 & 4 & 5 \\
\hline 2 & Gambar yang di sajikan jelas atau tidak buram & 5 & 5 & 5 & 5 & 4 & 5 & 5 \\
\hline 3 & $\begin{array}{l}\text { Kalimat-kalimat yang digunakan dalam } \\
\text { bahan ajar jelas dan mudah dipahami }\end{array}$ & 5 & 5 & 5 & 5 & 4 & 4 & 5 \\
\hline 4 & $\begin{array}{l}\text { Sampul bahan ajar menarik dan } \\
\text { mencerminkan isi bahan ajar }\end{array}$ & 5 & 4 & 5 & 4 & 4 & 5 & 5 \\
\hline 5 & $\begin{array}{l}\text { Adanya keterangan pada setiap gambar yang } \\
\text { di sajikan dalam bahan ajar }\end{array}$ & 5 & 5 & 5 & 4 & 5 & 5 & 5 \\
\hline 6 & Gambar yang di sajikan menarik & 5 & 5 & 4 & 5 & 5 & 5 & 5 \\
\hline 7 & $\begin{array}{l}\text { Daftar isi sudah runtut, jelas dan mudah } \\
\text { dipahami }\end{array}$ & 4 & 4 & 5 & 5 & 5 & 5 & 5 \\
\hline 8 & Gambar yang di sajikan sesuai dengan materi & 4 & 4 & 4 & 5 & 4 & 5 & 5 \\
\hline
\end{tabular}




\begin{tabular}{|c|c|c|c|c|c|c|c|c|}
\hline 9 & $\begin{array}{l}\text { Materi bahan ajar ini berkaitan dengan } \\
\text { kehidupan sehari-hari }\end{array}$ & 4 & 4 & 4 & 4 & 5 & 5 & 4 \\
\hline 10 & $\begin{array}{l}\text { Penyajian materi dalam baharn ajar ini } \\
\text { mendorong saya berdiskusi dengan teman- } \\
\text { teman yang lain }\end{array}$ & 5 & 5 & 5 & 4 & 5 & 5 & 5 \\
\hline 11 & Saya dapat memahami materi dengan mudah & 4 & 4 & 4 & 5 & 5 & 5 & 5 \\
\hline 12 & $\begin{array}{l}\text { Saya sangat tertarik menggunakan bahan ajar } \\
\text { ini untuk belajar }\end{array}$ & 4 & 4 & 5 & 4 & 4 & 4 & 5 \\
\hline 13 & Soal-soal sesuai dengan bahan ajar & 4 & 5 & 4 & 5 & 5 & 5 & 5 \\
\hline 14 & $\begin{array}{l}\text { Gambar dalam bahan ajar mudah dimengerti } \\
\text { dan sebagai acuan untuk belajaar lebih efektif }\end{array}$ & 4 & 4 & 5 & 5 & 5 & 4 & 5 \\
\hline 15 & Kemenarikan tampilan fisik buku bahan ajar & 5 & 5 & 5 & 5 & 5 & 5 & 5 \\
\hline & $\begin{array}{l}\text { Skor Total Per Siswa } \\
\text { Rata-rata } \\
\text { Persentase }\end{array}$ & $\begin{array}{l}68 \\
70 \\
93\end{array}$ & 68 & 70 & 70 & 70 & 71 & 73 \\
\hline
\end{tabular}

Sumber: Data Primer yang diolah, 2018

Proses uji coba pertama berlangsung selama 2 jam pelajaran (70 menit) pada saat jam pelajaran ekonomi. Selama proses tersebut peneliti tetap berada disekitar siswa dan membimbing apabila ada kesulitan yang dihadapi siswa dalam pelaksanaan uji coba. Setelah melakukan analisis terhadap data dalam Tabel 4.3 tersebut, didapatkan persentase keefektifan bahan ajar sebesar 93,3\%.

\section{Respon Guru dan Siswa}

\section{a. Respon Guru}

Data respon guru diperlukan dalam proses pengembangan ini untuk mengetahui kevalidan ataupun kepraktisan bahan ajar pada saat uji kelompok terbatas. Data berupa skor, tanggapan dan saran dari guru digunakan sebagai pertimbangan dalam melakukan revisi bahan ajar. Tanggapan guru tersebut dikumpulkan melalui angket yang diberikan peneliti pada guru ekonomi kelas X, yakni Bapak Ihsani, M.Pd. Berikut adalah data kevalidan bahan ajar tersebut disajikan dalam tabel 4 berikut.

Tabel 4. Data Kevalidan Bahan Ajar oleh Guru

\begin{tabular}{clc}
\hline No & \multicolumn{1}{c}{ Aspek yang Dinilai } & Skor \\
\hline 1 & Materi dalam perangkat lengkap dan mudah untuk dipahami & 4 \\
2 & $\begin{array}{l}\text { Kalimat-kalimat yang digunakan dalam bahan ajar jelas dan mudah } \\
\text { dipahami }\end{array}$ & 5 \\
3 & $\begin{array}{l}\text { Petunjuk penggunaan buku panduan guru dengan bahan ajar siswa sudah } \\
\text { jelas dan mudah dimengerti }\end{array}$ & 4 \\
4 & Sampul bahan ajar menarik dan mencerminkan isi bahan ajar & 5 \\
5 & Isi Materi sudah sesuai topic & 5 \\
6 & Daftar isi sudah runtut, jelas dan mudah dipahami & 5 \\
\hline
\end{tabular}




\begin{tabular}{clc}
\hline 7 & $\begin{array}{l}\text { Keakuratan Contoh-contoh jelas membantu pemahaman siswa dalam } \\
\text { belajar }\end{array}$ & 5 \\
8 & Konsep-konsep yang ditampilkan akurat dan mudah dipahami & 4 \\
9 & Bahan ajar ini dapat memotivasi siswa untuk belajar & 5 \\
10 & Bahan ajar ini telah menyertakan sekitar sebagai sumber belajar & 5 \\
11 & Soal-soal sesuai dengan isi bahan ajar & 4 \\
12 & Gambar dalam bahan ajar mudah dimengerti dan sebagai acuan untuk & 5 \\
& belajar lebih efektif & 5 \\
13 & Kesesuaian materi dengan kehidupan sehari-hari yang ada & 5 \\
14 & Gambar yang disajikan sesuai dengan materi & $\mathbf{6 6}$ \\
& Total Skor & $\mathbf{9 4 , 2 \%}$ \\
\hline
\end{tabular}

\section{Sumber: Data Primer yang diolah, 2018}

Skor yang diberikan respon guru terhadap bahan ajar model pembela menunjukkan persentase rata-rata sebesar 94,2\%. Berdasarkan persentase yang didapatkan bahan ajar tersebut termasuk dalam kategori sangat sangat valid dan praktis untuk di gunakan oleh siswa.

\section{b. Respon Siswa}

Angket respon siswa diberikan kepada 7 siswa kelas $\mathrm{X}$ saat pelaksanaan pembelajaran ekonomi dengan menggunakan model pembelajaran kooperatif tipe CIRC. Berikut penjabaran data tersebut pada tabel 5 .

Tabel 5. Data Respon Siswa

\begin{tabular}{lcc}
\hline \multicolumn{1}{c}{ Nama Siswa } & Skor Total & Persentase (\%) \\
\hline Idatul Barokah & 68 & $90,6 \%$ \\
Haerina Egiarti & 68 & $90,6 \%$ \\
Baiq Siti Hidayati & 70 & $93,3 \%$ \\
Wadi M. Syafa & 70 & $93,3 \%$ \\
Siti Mukarromah & 70 & $93,3 \%$ \\
Riki Nur Hanan & 71 & $94,6 \%$ \\
Suhaili Yahya & 73 & $97,3 \%$ \\
\hline Rata-rata & $\mathbf{7 0}$ & $\mathbf{9 3 , 2 \%}$ \\
\hline
\end{tabular}

Sumber: Data Primer yang diolah, 2018

Berdasarkan data dalam tabel 5 tersebut didapatkan bahwa persentase rata-rata siswa terhadap bahan ajar model pembelajaran kooperatif tipe CIRC sebesar 93,2\%. Selain itu siswa juga memberikan tanggapan yang positif serta saran yang membangun untuk bahan ajar tesebut.

\section{c. Hasil Belajar}


Penilaian hasil belajar siswa dengan kriteria yang telah ditentukan. Kriteria hasil belajar yang dimaksud dalam penelitian ini disajikan dalam tabel 6 .

Tabel 6. Persentase Proses Belajar Siswa

\begin{tabular}{lll}
\hline No & Persentase $(\%)$ & Tingkat Proses belajar siswa \\
\hline 1 & $85,01-100,00$ & Sangat baik \\
2 & $70,01-85,00$ & Baik \\
3 & $50,01-70,00$ & Kurang baik \\
4 & $01,00-50,00$ & Tidak baik \\
\hline
\end{tabular}

Diadaptasi dari Trianto, 2009.

Adapun perolehan nilai rata-rata hasil belajar siswa dapat disajikan dalam tabel 7 berikut ini.

Tabel 7. Perolehan Belajar Siswa

\begin{tabular}{|c|c|c|c|c|}
\hline No & Nama & JK & Nilai & KKM \\
\hline 1 & Ayu Sundari & $\mathrm{P}$ & 75 & Mencapai \\
\hline 2 & Dewi Muliana & $\mathrm{P}$ & 75 & Mencapai \\
\hline 3 & Edi Agus Kurniawan & $\mathrm{L}$ & 75 & Mencapai \\
\hline 4 & Bq Siti Hidayati & $\mathrm{P}$ & 88 & Mencapai \\
\hline 5 & Herlina Handayani & $\mathrm{P}$ & 88 & Mencapai \\
\hline 6 & Wadi M Syapa & $\mathrm{L}$ & 100 & Mencapai \\
\hline 7 & Homisatun Nisak & $\mathrm{P}$ & 88 & Mencapai \\
\hline 8 & Siti Mukarromah & $\mathrm{L}$ & 88 & Mencapai \\
\hline 9 & Lalu Muhammad Haeri Ibrahim & $\mathrm{L}$ & 75 & Mencapai \\
\hline 10 & Idatul Barokah & $\mathrm{P}$ & 88 & Mencapai \\
\hline 11 & M. Irjan Arifin & $\mathrm{L}$ & 88 & Mencapai \\
\hline 12 & Suhaeli Yahya & $\mathrm{L}$ & 88 & Mencapai \\
\hline 13 & Marsindi Anggraini & $\mathrm{P}$ & 80 & Mencapai \\
\hline 14 & Muh. Agus Arifin Jaelani & $\mathrm{L}$ & 88 & Mencapai \\
\hline 15 & Muh. Faruq Al-Farozi & $\mathrm{L}$ & 88 & Mencapai \\
\hline 16 & Muh. Salman Alfarisi & $\mathrm{L}$ & 75 & Mencapai \\
\hline 17 & Muhammad Hariqi & $\mathrm{L}$ & 75 & Mencapai \\
\hline 18 & Muhammad Harsani & $\mathrm{L}$ & 88 & Mencapai \\
\hline 19 & Riki Nur Hanan & $\mathrm{L}$ & 88 & Mencapai \\
\hline 20 & Haerina Egiarti & $\mathrm{P}$ & 75 & Mencapai \\
\hline
\end{tabular}




\begin{tabular}{lllll}
\hline 21 & Muhammad Zainuddin Sani & L & 88 & Mencapai \\
22 & Muhammad Zulkifli & L & 88 & Mencapai \\
23 & Novi Andriani & P & 100 & Mencapai \\
24 & Nurul Ilham & P & 88 & Mencapai \\
25 & Ria Mariska & P & 80 & Mencapai \\
\hline Rata - Rata & & 84,8 & \\
\hline
\end{tabular}

Sumber: Data primer yang diolah, 2018

Adapun tabel distribusi frekuensi hasil belajar siswadapat dilihat pada tabel 8 berikut ini.

Tabel 8. Distribusi Frekuensi Variabel Hasil Belajar Siswa

\begin{tabular}{cccc}
\hline No & Interval Kelas & Frekuensi & Frekuensi Relatif(\%) \\
\hline 1 & $61-70$ & 0 & 0 \\
2 & $71-80$ & 9 & 36 \\
3 & $81-90$ & 14 & 56 \\
4 & $91-100$ & 2 & 8 \\
\hline & Jumlah & $\mathbf{2 5}$ & $\mathbf{1 0 0}$
\end{tabular}

Sumber: Data primer yang diolah, 2018

Berdasarkan tabel 7 di atas, frekuesi variebel hasil belajar siswa pada interval 71 80 sebanyak 9 siswa (36\%), interval 81-90 sebanyak 14 siswa (56\%), interval 91-100 sebanyak2 siswa (8\%). Berdasarkan data pada tabel 8 diketahui bahwa perolehan nilai rata-rata hasil belajar siswa sebesar 84,8 . Selain itu $100 \%$ siswa telah mencapai kriteria ketuntasan minimal (KKM) yakni 70. Sesuai dengan kriteria yang telah ditentukan, model pembelajaran kooperatif tipe CIRC dapat dikategorikan efektif karena perolehan rata-rata hasil belajar siswa lebih dari 80 dan lebih dari $80 \%$ siswa telahmencapai KKM. Dengan telah terpenuhinya kriteria ketercapaian hasil belajar dan keterampilan proses belajar yang ditentukan, maka dapat dikatakan bahan ajar model pembelajaran kooperatif tipe CIRC meningkatkan hasil belajar siswa.

Penelitian dan pengembangan yang dilakukan yaitu berupa pengembangan bahan ajar, dimana penelitian dan pengembangan ini bertujuan untuk mengetahui keefektifan Bahan Ajar model Pembelajaran kooperatif tipe CIRC Pada Kelas X SMA NW Suralaga. 
Dalam penelitian ini produk yang dikembangkan adalah model pembelajaran kooperatif tipe CIRC, didalam bahan ajar terdapat kata-kata mutiara untuk memberikan motivasi kepada siswa, memuat 1 pokok bahasan yaitu, masalah ekonomi yang telah disajikan dengan lebih efektif dan efisien, soal-soal latihan yang menyenangkan. Desain bahan ajar yang menarik dan disertai dengan gambar-gambar yang sesuai dengan materi dan model kooperatif tipe CIRC.

Sebelum diujicobakan bahan ajar terlebih dahulu divalidasi oleh tim ahli untuk mengetahui apakah bahan ajar tersebut sudah valid atau tidak, sehingga dapat digunakan dalam penelitian. Hasil validasi ahli merupakan dasar yang dapat menentukan layak tidaknya produk yang dikembangkan untuk digunakan oleh siswa. Validasi dilakukan oleh 2 orang ahli yaitu pak Ikhsan, M.Pd sebagai ahli materi (validator I), Bapak Roni Amrulloh, M.Hum sebagai ahli bahasa (validator II).

Keseluruhan skor yang diberikan para pakar pada setiap aspek, kemudian diakumulasikan dan dirata-rata. Hasil validasi oleh validator I sebesar $72 \%$ yang menunjukkan bahwa produk yang dihasilkan layak (valid). Meskipun bahan ajar sudah dinyatakan valid oleh pakar materi tetapi masih perlunya perbaikan, seperti cover harus diganti. Perolehan nilai dari pakar bahasa yaitu validator II sebesar $76 \%$ yang menunjukkan bahwa produk yang dihasilkan layak (valid). Hasil penilaian dari validator II menyebutkan, produk yang dikembangkan masih perlu perbaikan seperti kalimat efektif dan pedoman umum ejaan Bahasa Indonesia.

Hasil penilaian oleh pakar I, II didapatkan bahwa produk yang dihasilkan layak digunakan oleh siswa yaitu kelas X SMA NW Suralaga. Hasil validasi ahli menunjukkan bahwa produk yang dihasilkan dapat diujicobakan pada subjek yang telah ditentukan yaitu siswa kelas X SMA NW Suralaga sebanyak 25 orang. Dari kegiatan uji coba tersebut diperoleh data berupa hasil respon siswa dan hasil respon guru terhadap bahan ajar model pembelajaran kooperatif tipe CIRC.

Sedangkan respon siswa terhadap produk yang diujicobakan diperoleh persentase rata-rata 93,2\% dalam kategori sangat baik. Hal ini dikarenakan bahan ajar model pembelajaran kooperatif tipe CIRC sudah melalui tahap bimbingan, penilaian pakar dan hasil revisi, sehingga siswa memberikan respon yang sangat baik. Dari hasil validasi model pembelajaran kooperatif tipe CIRC materi masalah ekonomi yang telah dikembangkan dalam penelitian, maka produk yang dihasilkan yaitu, model pembelajaran 
kooperatif tipe CIRC pada materi masalah ekonomi kelas X SMA NW Suralaga Tahun Pelajaran 2017/2018.

Tujuan pokok penggunaan model pembelajaran kooperatif tipe CIRC adalah untuk mengaktifkan kembali semangat belajar siwa serta mengembangkan kemampuan bekerjasama. Oleh sebab itu guru sebagai pelaksana pembelajaran harus mengutamakan proses yang mendukung terciptanya suasana kerja kelompok. Guru masih perlu meneliti terus-menerus untuk membuktikan apakah model pembelajaran kooperatif tipe CIRC sesuai dengan karakteristik siswa.

\section{Kesimpulan}

Kajian produk pengembangan yang disajikan adalah pengembangan model pembelajaran kooperatif tipe CIRC yang menghasilkan produk (silabus, RPP, buku model pembelajaran). Berdasarkan data yang terkumpul dalam analisis pengembangan model pembelajaran kooperatif tipe CIRC setelah di validator oleh beberapa ahli (ahli isi, ahli bahasa). Dari validasi ahli materi (ahli isi) memperoleh nilai rata-rata sebesar $72 \%$ dan termasuk kategori cukup valid, ahli bahasa memperoleh nilai rata-rata sebesar $76 \%$ dan termasuk kategori cukup valid. Setelah dilakukan validasi dan merevisi produk yang dihasilkan (silabus, RPP, buku model pembelajaran) dari para ahli barulah diuji coba di lapangan (guru dan siswa) sehingga dapatditarikkesimpulan bahwa pengembangan model pembelajaran kooperatif tipe CIRC menghasilkan produk (silabus, RPP, dan buku model pembelajaran) ini dapat diketahui bahwa efektif untuk digunakan dalam proses pembelajaran di SMA NW Suralaga, ini dapat dilihat dari respon siswa mendapatkan nilai persentase sebesar 94,2\% dan respon guru mendapatkan nilai persentase sebesar 93,2\%.

\section{Daftar Rujukan}

Ariyandika, N., Rohana, R., \& Jayanti, J. (2017). Pengaruh Model Pembelajaran Kooperatif Tipe Cooperative Integrated Reading and Composition (CIRC) terhadap Kemampuan Pemecahan Masalah Matematis Siswa di SMP Negeri 22 Palembang. Nabla Dewantara: Jurnal Pendidikan Matematika, 2(1), 40-51.

Borg dan Gall. (2003). Educational Research an Introduction, Seventh Editions. United State of America: University of Oregon.

Gustariani, G. (2017). Penerapan Model Pembelajaran Kooperatif Tipe Cooperative Integrated Reading and Composition (CIRC) Untuk Meningkatkan Hasil Belajar 
Fisika Pada Pokok Bahasan Gejala Dan Ciri Ciri Gelombang Siswa Kelas XII Sman 9 Pekanbaru. JURNAL PAJAR (Pendidikan dan Pengajaran), 1(1), 79-84.

Hamalik, Oemar. (2013). Proses Belajar Mengajar. Jakarta: PT Bumi Aksara.

Ibrahim, Muhsin, dkk. (2000). Pembelajaran Kooperatif. Surabaya: University Press.

Ipuh, M. T. N. (2015). The effects of using CIRC model on the English learning skills among junior high school students. Journal of Education and Learning (EduLearn), 9(2), 117-124.

Komalasari, Kokom. (2011). Pembelajaran Konseptual Konsep dan Aplikasi. Bandung: Refika Aditama.

Lie, Anita. (2002). Cooperative Learning. Jakarta: Grasindo.

Parinu, K. L. W., Darmawiguna, I. G. M., \& Wahyuni, D. S. (2013). Pengaruh Model Pembelajaran Cooperative Integrated Reading and Composition (CIRC) Terhadap Hasil Belajar TIK Siswa Kelas VII (Studi Kasus: SMP Negeri 4 Singaraja) Tahun Ajaran 2012/2013. KARMAPATI (Kumpulan Artikel Mahasiswa Pendidikan Teknik Informatika), 2(6), 731-735.

Purnamasari, Wilis Indah. (2017). Pengaruh Model Pembelajaran Kooperatif Tipe CIRC (Cooperative Integrated Reading and Composition) Terhadap Kemampuan Menemukan Kalimat Utama Dalam Paragraf Pada Siswa Kelas IV SDN Blimbing Dan Kalirong. Jurnal Simki Pedagogia, 1(1), 1-11.

Slavin, R. E. (2010). Cooperative Learning Teori, Riset dan Praktik. Bandung: Nusa Media.

Sudjana. N. (2009). Penilaian Hasil Belajar Mengajar. Bandung: PT Remaja Rosdakarya.

Trianto, (2009). Mendesain Model Pembelajaran Inovatif Progresif. Surabaya: Kencana. 